Pesq. Vet. Bras. 36(2):119-122, fevereiro 2016 DOI: $10.1590 / \mathrm{S} 0100-736 \mathrm{X} 2016000200009$

\title{
Protocol for collection and separation of bone marrow mononuclear cells in Chlorocebus aethiops ${ }^{1}$
}

\author{
Érika Branco ${ }^{2 *}$, Klena Sarges Marruaz Silva ${ }^{3}$, Maria de Fátima Assis ${ }^{3}$, Edivaldo \\ Herculano Corrêa de Oliveira ${ }^{3}$, Ana Rita de Lima ${ }^{2}$, Ana Cleide Guimbal de Aquino ${ }^{2}$, \\ Rosa Cabral $^{2}$ and Maria Angelica Miglino ${ }^{4}$
}

\begin{abstract}
Branco E., Silva K.S.M., Assis M.F., Oliveira E.H.C., Lima A.R., Aquino A.C.G., Cabral R. \& Miglino M.A. 2016. Protocol for collection and isolation of bone marrow mononuclear cells in Chlorocebus aethiops. Pesquisa Veterinária Brasileira 36(2):119-122. Instituto de Saúde e Produção Animal, Faculdade de Medicina Veterinária, Universidade Federal Rural da Amazônia, Av. Presidente Tancredo Neves 2501, Bairro Montese, Belém, PA 66077-530, Brazil. E-mail: ebranco.ufra@gmail.com

Chlorocebus aethiops is a species of non-human primate frequently used in biomedical research. Some research involves this species as an experimental model for various diseases and possible treatment with stem cells. The bone marrow is one of the main sources of these cells and provides easy access. The aim of this study was to standardize the protocol of collection and separation of bone marrow in C. aethiops. Ten animals were submitted to puncture of bone marrow with access to the iliac crest and cell separation by density gradient. The bone marrow of $C$. aethiops had an average of $97 \%$ viability. From the results achieved, we can conclude that $C$. aethiops is an excellent model to obtain and isolate mononuclear cells from bone marrow, fostering several studies in the field of cell therapy.
\end{abstract}

INDEX TERMS: Bone marrow, stem cell, mononuclear cells, Chlorocebus aethiops.

\begin{abstract}
RESUMO.- [Protocolo para colheita e isolamento de células mononucleares de medula óssea em Chlorocebus aethiops.] Chlorocebus aethiops é uma espécie de primata não humano frequentemente utilizados em pesquisa biomédica. Algumas pesquisas envolve esta espécie como modelo experimental para várias doenças e possível tratamento com células-tronco. A medula óssea é uma das principais fontes destas células e proporciona fácil acesso. 0 objetivo deste estudo foi o de padronizar o protocolo de coleta e separação de medula óssea em C. aethiops. Dez animais foram submetidos a punção de medula óssea com acesso à crista ilíaca e separação de células por gradiente de densidade.
\end{abstract}

\footnotetext{
${ }^{1}$ Received on January 1, 2015.

Accepted for publication on December 10, 2015.

${ }^{2}$ Instituto de Saúde e Produção Animal (ISPA), Faculdade de Medicina Veterinária, Universidade Federal Rural da Amazônia (UFRA), Av. Presidente Tancredo Neves 2501, Bairro Montese, Belém, PA 66077-530, Brazil. *Corresponding author: ebranco.ufra@gmail.com

${ }^{3}$ Instituto de Evandro Chagas (EC), Centro Nacional de Primatas (CENP), Rodovia Br-316 Km 7, s/n, Bairro Levilândia, Ananindeua, PA 67030-000, Brazil.

${ }^{4}$ Department of Surgery of the University of São Paulo, Faculty of Veterinary Medicine and Animal Science (FMVZ/USP), Avenida Prof. Dr. Orlando Marques Paiva, 87, Bairro Cidade Universitária, São Paulo, SP 05508-270, Brazil.
}

A medula óssea de C. aethiops tinha uma média de $97 \%$ de viabilidade. A partir dos resultados obtidos, podemos concluir que $C$. aethiops é um excelente modelo para obter e isolar células mononucleares da medula óssea, promovendo vários estudos no campo da terapia celular.

TERMOS DE INDEXAÇÃO: Medula óssea, células-tronco, células mononucleares, Chlorocebus aethiops.

\section{INTRODUCTION}

Chlorocebus aethiops, popularly known as an African green monkey, is one of the most important non-human primates and biomedical model used in scientific research, whose number of citations in articles, in the last decade, stored by PubMed, is similar to the number of citations of the studies that used the Rhesus monkey. The continuous increase of its use is due to the fact that the alternative species to the use of Rhesus monkeys, being of management relatively easy and high prolificacy in captivity (Freimer et al. 2007). Carlsson et al. (2004), carried out a survey of the use of non-human primates in biomedical research, and only in 2001, it was observed that the species was the most used one in published researches of the whole world, mainly in the areas of microbiology and 
biochemistry, with emphasis on research using the cultivation of cells.

Concerning the bone marrow, this is located between the trabeculae in the spongious bone, being very vascularized and isolated by the endosteum, constituting almost 5\% of the total body weight and taking important roles such as being responsible for the formation of blood cells (Gartner \& Hiatt 2001). In adult animals, the medullar channel is replaced by adipose tissue and the active bone marrow is restricted only in the bone epiphysis, which has a greater quantity of spongious bone (Raskin 1998).

In the bone marrow of adult mammals, the blood cells develop a complex network of factors of regulating cellular and humoral (Dexter et al. 1983). This means that we remove the adult stem cells, which consist of a series of populations of pluripotent cells, being hematopoietic and mesenchymal, in intimate contact with the stroma (Siminiak 2003). These cells are derived from primitive cells, supposedly the hemangioblasts (Orlic 2004), in which both cell types, when used therapeutically, assist mainly in vasculogenesis (Poulson et al. 2002). Martin-Rendon (2003) makes mention of plasticity of the stem cells, which have great ability to acquire phenotype of other cells of a different tissue or organ.

In adult tissues there are reserves of cells with the capacity to multiply themselves, differentiating themselves and, at the same time, maintaining their own reserve of undifferentiated cells, which are responsible for maintaining the integrity of adult tissues, the repair of injured tissues and the remodeling of tissues and organs (Zago \& Covas 2006).

The non-human primates are animals of extreme importance and use in experimental studies, serving as potential models for the clinical trials of various pathologies. In this way, numerous scientific investigations involving cellular therapy, the present study aimed to evaluate the puncture technique of bone marrow in this species, as well as to define the protocol of separation and viability of mononuclear cells in adults Chlorocebus aethiops. However, it is reported that there are no literary records of such procedures in non-human primates, so that, we anchor publications about other mammals, which already have such established protocols.

\section{MATERIALS AND METHODS}

All the procedures of this study were in accordance with the Bioethics Committee on Animal Research (CEPAN/IEC/SVS/MS), under the protocol number 018/2009.

The entire squad held annual health check up, had not been identified until that date and there was no virus affecting the existing squad.

Collection protocol. We used 10 Chlorocebus aethiops, adult, male, with a mean weight of $4 \mathrm{~kg}$, belonging to the National Center of Primates (CENP-IEC/SVS/MS), Ananindeua, PA.

After a period of solid and water fasting of 12 hours, the animals were premedicated with association of the hydrochloride of tiletamine and zolazepan ( $8 \mathrm{mg} / \mathrm{kg} \mathrm{IV)}$; it was performed to maintain anesthesia with isofluorane to $5 \%$.

To obtain the bone marrow, the iliac crest was selected; with the animal on lateral decubitus, we performed trichotomy and antisepsis in the region, followed by the local anesthesia with lidocaine hydrochloride $2 \%$, without vessel constrictor, followed by puncture with hypodermic needle disposable (40x12), adapting to the technique described by Crow \& Walshaw (2000), and by removing the bone marrow of each animal in syringes heparinized $(0.2 \mathrm{ml}$ heparin sodium, 5000UI/ml) (Fig.1A). Punctures were performed in several directions of the same iliac crest, using a single input and reaching a total average of $13 \mathrm{ml}$ of bone marrow by the animal. The samples were immediately transported to the laboratory under refrigerated conditions for carrying out the process of cell separation.

At the end of all the collects, each animal received analgesic medication (tramadol hydrochloride $2 \mathrm{mg} / \mathrm{kg}$, IM) during 3 days.

Cell separation protocol. Initially, a dilution was made of the bone marrow collected in saline solution $0.9 \%$ (1:1). Then, cell separation was done in conical tube by gradient density in the proportion 2:1 of bone marrow diluted and Ficoll-Paque ${ }^{\mathrm{TM}}$ Plus, being slowly and carefully added to this with a Pasteur pipette (Fig.1B), avoiding the homogenization between the solutions.
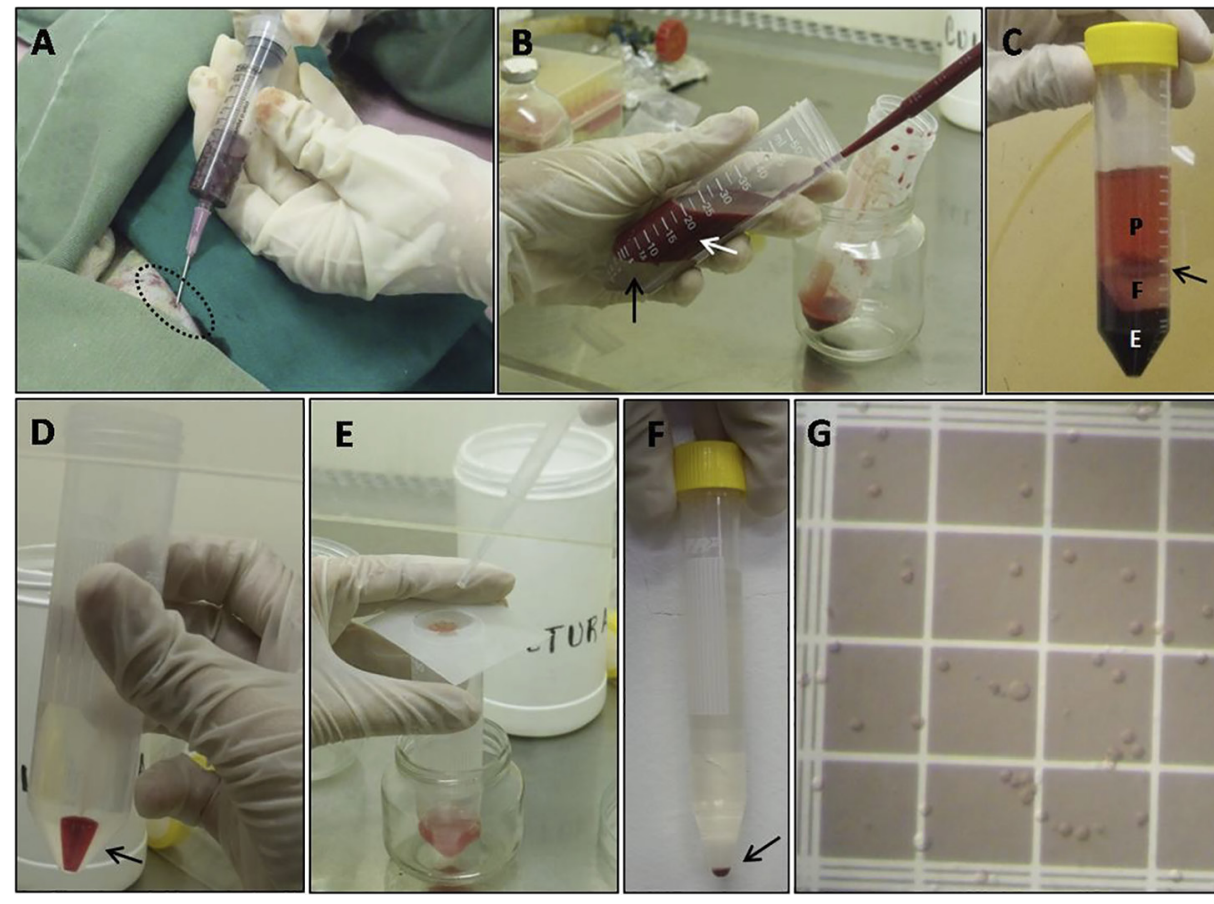

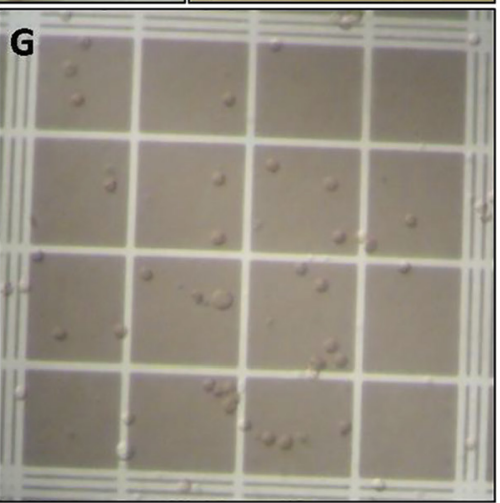

Fig.1. Protocol of collection and separation of bone marrow mononuclear cells (BMMO) in Chlorocebus aethiops. (A) Extraction of bone marrow in iliac crest (circle). (B) Cell separation of bone marrow (white arrow) for density gradient with Ficoll-Paque (black arrow). (C) Formation of the halo of bone marrow mononuclear cells after centrifugation (arrow), plasma (P), Ficoll-Paque fraction (F) and erythrocytes (E). (D) Mononuclear cell pellet after washing with saline. (E) Mononuclear cells filtrating in 200mesh nylon net. (F) Pellet formation of bone marrow mononuclear cells after separation process. (G) Counting and viability test of bone marrow mononuclear cells in Neubauer chamber. 
This new solution (diluted bone marrow + Ficoll) was centrifuged for 20 minutes, at $2000 \mathrm{~g}$ and $20^{\circ} \mathrm{C}$, so that the cells of interest formed a halo between the different gradients obtained (Fig.1C), which was collected with a Pasteur pipette and placed in a new conical tube, adding saline solution $0.9 \%$ in the proportion $1: 6$ and performing another centrifugation $\left(2000 \mathrm{~g}\right.$ at $\left.20^{\circ} \mathrm{C} / 7 \mathrm{~min}\right)$. The cells were washed two more times in saline solution $0.9 \%$ under the same protocol of centrifugation, and subsequently filtered through stainless steel 200 Mesh (Fig.1D e E). The product was resuspended again in saline and centrifuged obeying the same protocol as described in this study (Fig.1F).

At the end of this process, the supernatant was discarded and the cluster of bone marrow mononuclear cells (BMMC) was resuspended in $2 \mathrm{ml}$ of saline, carrying out the separation of a small aliquot for cell viability test, with Trypan blue (Merck), in a Neubauer chamber (Fig.1G).

\section{RESULTS}

The iliac crest of Chlorocebus aethiops, located between the coxal and sacral tuberosity, with a mean length of $2 \mathrm{~cm}$, even being a tiny one, is easily accessed when the animal is in lateral decubitus, requiring minimum physical strength (Fig.1A) for collection of $13 \mathrm{ml}$ bone marrow, which was immediately maintained under refrigeration and sent to the laboratory to initiate cell separation protocol. It was not detected lipid accumulation in the cell separation.

It was observed the formation of the halo of bone marrow mononuclear cells of $C$. aethiops, after cell separation, by the density gradient which is very visible, making it easy to collect the same (Fig.1C), allowing the formation of pellet (Fig.1D). The cell viability from our samples achieved average $97 \%$ after the use of Trypan blue technique (Fig.1G). Our samples were not maintained in cultivation and were immediately used as experimental therapy in correlated study.

\section{DISCUSSION}

The positioning of the iliac crest in Chlorocebus aethiops for bone marrow collection is in contrast to Tognoli's (2009) idea, which suggests that the collection of bone marrow must be made in ventral decubitus in dogs, and to Branco et al. (2012), who suggest the ventro-lateral decubitus in swine; however, such positioning makes the collection difficult in the case of non-human primates, due to the anatomical arrangement of the coxal, since these animals are also bipedal.

The iliac crest was elected instead of certain long bones because according to Larue (2005) they are easily susceptible to fracture when the bone marrow is extracted, facing the imminent execution of lever movement with needle, which creates a separation force of the bone fragments. According to Bacipalugo et al. (2002), the amount of bone marrow with a higher number of progenitor cells is found in iliac crest. Due to its smallness, the first bone barrier post periosteum (compact bone) is quickly outdated, reaching immediately the region of the spongious bone; however, the blood flow in the suction spend comparatively slowly, which has not prevented us from carrying out the collection with the average of $13 \mathrm{ml}$ of bone marrow. In disagreement with the suggestion of Olsson et al. (2009), we do not maintain healthy cells at room temperature during the transportation to the laboratory, once low temperatures decrease the cellular metabolism (Porter 1998).
As described by Samoto et al. (2009) in the separation of bone marrow of dogs, the lipid accumulation was not detected, a fact recorded in swine's by Branco et al. (2012); however, despite the liquid consistency of the material, we could notice the formation of small cell aggregates, independent of the use of anticoagulant at the time of collection, this fact was also observed by Alves et al. (2009) when they performed extraction of bone marrow from horses sternum. The authors also reported the presence of spicules in the samples, as well as gelatinous consistency of all the material, which was not observed in our study.

More evident than in dogs (Samoto et al. 2009), the halo formation of bone marrow mononuclear cells from C. aethiops, after cellular separation by gradient density is quite visible, making it easy to collect, in the same way as described by Branco et al. (2012) in swine, allowing the formation of pellet.

According to Thomas \& Storb (1970), the amount required for bone marrow transplantation, is usually estimated at $10-15 \mathrm{ml} / \mathrm{kg}$ of recipient weight. Generally, this volume contains an adequate number of progenitor cells to allow the grafting. Sutter (2007) pointed out that progenitor cells are concentrated in first few millilitres of blood marrow, leading us to use only $13 \mathrm{ml}$. The cell viability of bone marrow from $C$. aethiops, reached an average of $97 \%$ after exclusion of Trypan blue dye, being higher than that found by Perin et al (2003) in humans (96\%), more expressive when compared with the findings of Alves et al. (2009) in horses (86.9\%), however, slightly lower than the findings of Branco et al. (2012) in swine (98\%).

According to Olsson et al. (2009) some protocols about washing during the process of cell separation are performed with a mixture enriched with mineral, amino acids and essential components of proteins of foetal calf serum. However, to cheapen the cost of the study, the author used for each animal, sterile autologous serum associated with DMEM, to provide energy to the mononuclear cells from bone marrow of dogs and obtained viability of $90 \%$. As well as Branco et al. (2012), not relied on any special component to cell washing, replacing, also as described by the authors, the foetal calf serum by saline $0.9 \%$, though it is important to realize that our samples were not kept under cultivation, but immediately used as an experimental therapy in correlated study.

Finally, we can say that in the last decade, research on bone marrow mononuclear cells have revealed various possibilities for tissue repair, and quality of the regenerative processes when transplanted cells processed in a greater volume than or equal to $2 \times 10^{6}$ (Suter et al. 2004), $2 \times 10^{8} \mathrm{BMMC} / \mathrm{kg}^{-1}$ from the receptor (Nakage et al. 2006) and $1 \times 10^{8}$ (Branco et al. 2012). Our findings are consistent with the literature recommended, a time that on average, we got in $13 \mathrm{ml}$ of bone marrow from each animal $1 \times 10^{8}$ mononuclear cells.

\section{CONCLUSIONS}

It is essential that the bone marrow collection is performed in a surgical environment, preserving the asepsis and antisepsis of the puncture site, ensuring the quality and viability of the sample as well as the animal health. 
The lateral decubitus is the positioning of choice for puncturing the bone marrow in Chlorocebus aethiops, ensuring more safety, reducing the risks of bone injuries, such as fractures and ligament injuries.

The volume of bone marrow extracted from each animal with a mean of $4 \mathrm{~kg}$ provides safety to it, as well as positive results regarding the viability and total BMMC.

Regarding the success of protocol, for collection and separation, and being from $C$. aethiops, a primate non-human of the old world, with great genotype compatibility in relation to the man, we suggest this species as an excellent model for future studies in cell therapy.

Acknowledgements.- To Professor Doctor Elisabeth Conceição de Oliveira Santos from Evandro Chagas Institute (IEC) for her support given in the development of this study.

\section{REFERENCES}

Alves A.L.G., Vieira M.E.M., Barreira A.P.B., Mota L.S.L.S., Saito M.E., Kohayagawa A., Hussni C.A., Watanabe M.J. \& Oliveira P.G.G. 2009. Protocolo de isolamento de células mononucleares de medula óssea de equinos. Vet. Zootec. 16:650-655.

Bacipalugo A., Tong J., Podesta M., Piaggio G., Figari O., Colombo P., Sogno G., Tedone E., Moro F. \& Van Lint M.T. 2002. Bone marrow harvest for marrow transplantation: effect of multiple small $(2 \mathrm{ml})$ or large (20) $\mathrm{ml}$ aspirates. Bone Marrow Transplant 9:467-470.

Branco E., Cabral R., Gomes B.D., Kfoury Jr J.R. \& Miglino M.A. 2012. Bone marrow cells of swine: Collection and separation. Microsc. Res. Tech. 75:917-920.

Carlsson H.E., Steven J.S., Farah I. \& Hau J. 2004. Use of Primates in Research: a global overview. Am. J. Primatol. 63:225-237.

Crow E.S. \& Walshaw S.O. 2000. Colocação e cuidados com cateteres intravenosos, p.47-64. In: Ibid. (Eds), Manual de Procedimentos Clínicos em Cães, Gatos e Coelhos. Artes Médicas Sul, Porto Alegre.

Dexter T.M., Spooncer E., Varga J., Allen T.D. \& Lanotte M. 1983. Stromal cells and diffusible factors in the regulation of haemopoietic cell development, p.303-322. In: Killman S.V.A.A, Cronkite E.P. \& Muller-Berat C.N. (Eds), Haemopoietic Stem Cells. Benzo Symposium, Munksgaard, Copenhagen.

Freimer NB, Service SK, Ophoff RA, Jasinska AJ, McKee K, Villeneuve A, Belisle A, Bailey JN, Breidenthal SE, Jorgensen MJ, Mann JJ, Cantor RM, Dewar K, Fairbanks LA. 2007. A quantitative trait locus for variation in dopamine metabolism mapped in a primate model using reference sequences from related species. Proc Natl Acad Sci USA 104:1581115816.
Gartner L.P. \& Hiatt J.L. 2001. Tratado de Histologia em cores. Guanabara Koogan, Rio de Janeiro. 456p.

Larue S.M. 2005. Técnicas Atuais em Cirurgia de Pequenos Animais. Roca, São Paulo. 869p.

Martin-Rendon E. \& Watt S.M. 2003. Stem cell plasticity. Brit. J. Haematol. 122:877-891.

Nakage A.P. \& Santana A.E. 2006. Hematopoietic stem cells in dogs. Ciência Rural 36:325-329.

Olsson D.C., Pippi N.L., Martins D.B., Tognoli G.K., Santos Júnior E.B., Muller D.C., Lopes S.T.A., Marconato F., Mörchbächer P.D. \& Teixeira L.V. 2009. Colheita de medula óssea em cães: modelo para obtenção da fração total de células Mononucleares. Ciência Rural 39:141-147.

Orlic D. 2004. The strength of plasticity: stem cells for cardiac repair. Int. J. Cardiol. 95:S16-S19.

Perin E.C., Dohmann H.F.R., Borojevic R., Silva S.A., Sousa A.L.S., Mesquita C.T., Rossi M.I.D., Carvalho A.C., Dutra H.S., Dohmann H.J.F., Silva G.V., Belém L., Vivacqua R., Rangel F.O.D., Esporcatte R., Geng Y.J., Vaughn W.K., Assad J.A.R., Mesquita E.T. \& Willerson J.T. 2003. Transendocardial, autologous bone marrow cell transplantation for severe, chronic heart failure. Circulation 107:2294-302.

Porter M. 1998. The New Equine Sports Therapy. The Blood-Horse Inc., Lexington, KY. 205p.

Poulson R., Alison M.R., Forbes S.J. \& Wright N.A. 2002. Adult stem cell plasticity. J. Pathol. 197:441-456.

Raskin R. 1998. Manual de Cirurgia de Pequenos Animais. Manole, São Paulo. 2830p.

Samoto V.Y., Branco E., Ferreira G.J., Cabral R., Gregores G.B., Sousa A.L.S., Dohman H.F.R., Silva S.A., Takiya C.M., Rossi M.I.D., Borojevic R. \& Miglino M.A. 2009. Padrão de distribuição de células mononucleares de medula óssea em tecido cardíaco sadio por diferentes vias de infusão. Revta Bras. Cardiol. Invas. 17(2):220-226.

Siminiak T. \& Kurpisz M. 2003. Myocardial replacement therapy. Circulation 108:1167-1171.

Suter S.E., Gouthro T.A., McSweeney P.A., Nash R.A., Haskins M.E., Felsburg P.J. \& Henthorn P.S. 2004. Isolation and characterization of pediatric canine bone marrow CD34+ cells. Vet. Immunol. Immunopathol. 101:31-47.

Sutter W.W. 2007. Autologous cell-based therapy for tendon and ligament injuries. Clin. Tech. Equine Pract. 6:198-208.

Thomas E.D. \& Storb R. 1970. Technique for human marrow grafting. Blood 36:507-515.

Tognoli G.K., Olsson D.C. \& Martins D.B. 2009. Transplante autólogo de células mononucleares da medula óssea em úlcera de córnea experimental em cães. Ciência Rural 39:148-155.

Zago M.A. \& Covas D.T. 2006. Células Tronco, a Nova Fronteira de Medicina. Atheneu, São Paulo. 264. 